\title{
Comprehensive concept planning of urban greening based on ecological principles: a case study in Beijing, China
}

\author{
Feng Li $^{\mathrm{a}}$, Rusong Wang ${ }^{\mathrm{a}, *}$, Juergen Paulussen ${ }^{\mathrm{a}}$, Xusheng Liu ${ }^{\mathrm{b}}$ \\ ${ }^{a}$ Key Lab of Systems Ecology, Research Center for Eco-Environmental Sciences, Chinese Academy of Sciences, \\ P.O. Box 2871, Beijing 100085, China \\ ${ }^{\mathrm{b}}$ Resource and Environment College, Beijing Forestry University, Beijing 100083, China
}

Received 29 October 2003; received in revised form 15 April 2004; accepted 24 April 2004

\begin{abstract}
Greenspace is an important part of complex urban ecosystems and provides significant ecosystem services. It benefits urban communities environmentally, esthetically, recreationally and economically. Beijing Province is in north of China, and has a total area of $16,807.8 \mathrm{~km}^{2}$ and a population of about 13.8 million. This paper aims to develop a comprehensive conceptual framework for urban greening of Beijing Province based on landscape ecological principles. It attempts to answer how to establish an urban greening plan at the regional, city and neighborhood levels to achieve long-term sustainability. At the regional level, a big natural and semi-natural forest area in the northwest and an ecological buffer belt in the southeast are planned to protect the environmental quality of Beijing and provide habitats for wildlife. At the city level, a green network system of green wedges, parks and green corridors has been proposed. This green network helps to limit future urban expansion, improve urban environmental quality and serve as habitats and migration routes for wildlife. At the neighborhood level, green extensions and connections of riverside greenway, road greenway, parks and vertical greening permeate into the built-up areas. They provide open space close to residential areas and offer places for recreation. This three-level green system constitutes an integrated ecological network for urban sustainable development of Beijing. For future development of Beijing, urban parks, forestry, agriculture, water and infrastructure should be planned and designed in an integrated way. After this greenspace plan is legislated and completely realized, Beijing will develop an interconnected and integrated network of urban greenspaces. It has the prospect of achieving the aim of "Green Olympic City 2008" and the long-term goal of developing Beijing towards an "Eco-City".
\end{abstract}

(C) 2004 Elsevier B.V. All rights reserved.

Keywords: Urban greening; Urban greenspace; Ecosystem services; Landscape ecology; Ecological planning; Beijing; China

\footnotetext{
* Corresponding author. Tel.: +86 1062943807 ; fax: +861062943807.

E-mail addresses: lifengxus@yahoo.com.cn (F. Li), wangrs@mail.rcees.ac.cn (R. Wang).
}

\section{Introduction}

The world is becoming an increasingly urban place. Some $65 \%$ of the world's population is expected to be urban by the year 2025 (Schell and Ulijaszek, 1999). Due to fast urbanization, natural ecosystems are in- 
creasingly replaced by urban development. Urbanization increases the distance between people and natural space. To counter these trends, it is important to make sufficient provision of quality greenspace within urban areas as well as improve access to the countryside around towns.

Urban greenspaces are an important component of the complex urban ecosystem. Parks, forests and farmlands are three main types of urban greenspace, which have significant ecological, social and economic functions (Bradley, 1995; Shafer, 1999; Tyrväinen, 2001; Lütz and Bastian, 2002). People are eager to access these greenspaces for recreation and to experience nature (de Groot and van den Born, 2003; Lynn and Brown, 2003). Greenspace has significant ecosystem services, which are defined as "the benefits human population derives, directly or indirectly, from ecosystem functions" (Costanza et al., 1997). It can sequester carbon dioxide emissions and produce oxygen (Jo, 2002), purify air and water, regulate micro-climate, reduce noise (Bolund and Hunhammar 1999), protect soil and water (Pauleit and Duhme, 2000; Jim, 2001), maintain biodiversity (Attwell, 2000), and have recreational, cultural and social values (Savard et al., 2000; Tarrant and Cordell, 2002). Furthermore, greenspaces such as public parks, natural areas and golf courses can have a statistically significant effect on the sale price of houses in close proximity to those resources (Bolitzer and Netusil, 2000; Luttik, 2000). Thus, urban greenspace improves the urban environment, contributes to public health and increases the quality of life of urban citizens. In future, the social and spatial implications of new lifestyles, values, attitudes to nature and sustainability will even lead to higher demands for urban greenspace (Thompson, 2002).

The planning and management of urban greening is of significance to urban sustainable development (Miller, 1988; Grey, 1996; Teal et al., 1998). In Canada and the US, as well as in Europe, there has been a growing recognition among community groups and environmental organizations that brownfields hold enormous potential for "greening" city environments (Sousa, 2003; Kühn, 2003). Some studies have shown how green or open space planning based on ecological principles can be implemented. Flores et al. (1998) proposed ecological content, context, dynamics, heterogeneity and hierarchies as ecological principles for the development of a greenspace system for the New
York City region. Leitão and Ahern (2002) argued for a common framework that applies ecological knowledge in landscape and urban planning. Jim and Chen (2003) applied landscape ecological principles to the greenspace planning of Nanjing City, China. Ong (2003) proposed an ecological indicator - the green plot ratio (the single-side leaf area per unit ground area) - as a suitable measure for the greening in architecture and urban planning. Herzele and Wiedemann (2003) developed an integrated indicator to assess the accessibility and attractiveness of urban greenspace in four Flemish cities. Pauleit et al. (2003) proposed a more flexible approach named Accessible Natural Greenspace Standards Model to promote the natural greenstructure of towns and cities and devised a decision-support framework for its implementation. Li and Wang (2003) proposed a method for the evaluation, planning and prediction of ecosystem services of urban greenspace, applying landscape ecological principles, taking Yangzhou City in China as the case.

In Autumn 2002, the Beijing Municipal Institute of City Planning and Design asked the Research Center for Eco-Environmental Science, Chinese Academy of Sciences and two other institutes for scientific support to revise the current Beijing Urban Master Plan. Our research team was commissioned to develop a plan for Beijing based on ecological principles. It provides basic information, specific space-related objectives and a strategic conceptual framework for future eco-urban development of Beijing region. The study was finished by the end of July 2003.

This paper aims to outline the conceptual ecological framework developed in this study. It will then show how an actionable urban greening plan at the regional, city and neighborhood levels to achieve longterm sustainability could be developed for Beijing City.

\section{Study area}

Beijing Province is in the north of China and located at $39^{\circ} 38^{\prime}-41^{\circ} 05^{\prime} \mathrm{N}$ in the temperate climatic zone with a mean annual temperature of $12{ }^{\circ} \mathrm{C}$. Precipitation averages $640 \mathrm{~mm}$ per annum. It has a total area of $16,807.8 \mathrm{~km}^{2}$ and a population of about 13.8 million with an average population density of 821 persons $/ \mathrm{km}^{2}$ (Beijing Municipal Statistical Bureau, 2002). Beijing 


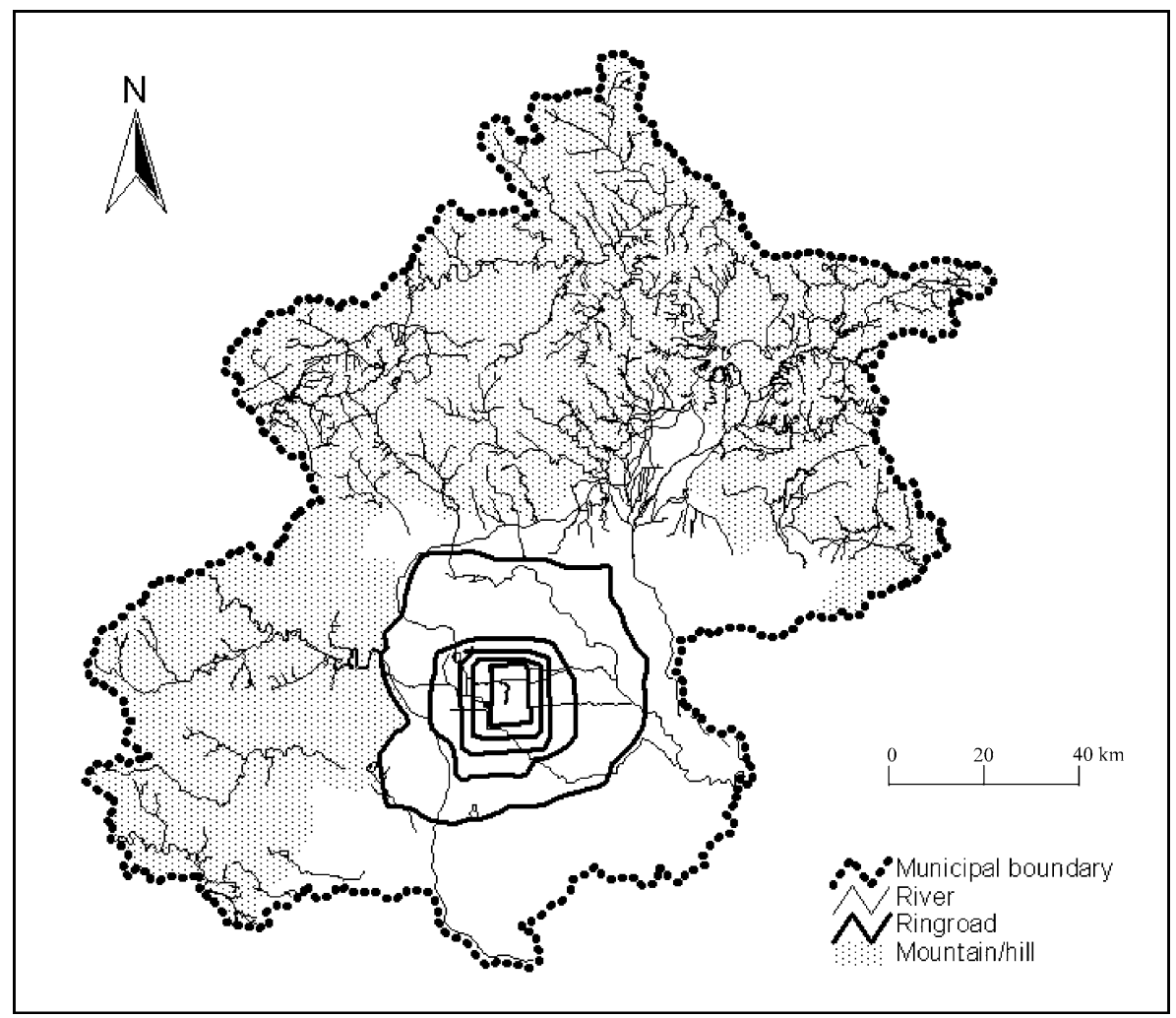

Fig. 1. Major landform features of Beijing Province.

Province's varied topography comprises mountains which account for $62 \%$ of the surface area and are located in the northwest, and the so called "Beijing Plain" in the southeast where the elevation is below $100 \mathrm{~m}$ above sea level. The plain covers $38 \%$ of Beijing Province, and is the main scene of urban extension (Fig. 1). The highest point above sea level is $2303 \mathrm{~m}$, and the lowest is $10 \mathrm{~m}$. Beijing has more than 200 rivers. Most rivers run from the northwest to the southeast through the city to join Bohai Bay in Tianjin. The original natural vegetation was deciduous broadleaf and evergreen coniferous forest. Due to human influence, most of the original natural vegetation has disappeared. The current natural forest vegetation is dominated by Pinus tabulaeformis, Quercus acutissima, Populus tomentosa, Betula platyphylla, and bush-grass communities.

Beijing has more than 3000 years of history. Beijing's road system can be briefly described as a network, with ringroads and radial roads as its arteries.
The road around the Forbidden City is named the first ring, and the ringroads beyond are the second, third, fourth and fifth ringroads in order of the radial distance from the center of the city (Fig. 1). Before 1949, Beijing's development was confined within the old town, now marked by the second ringroad. The Reform and Open Policy initiated in the 1980s brought a phase of rapid urbanization and further encroachment into the surrounding countryside.

\section{Problems of urban greening in Beijing}

\subsection{Extension of settlement area and encroachment of greenspace}

Over the last 10 years, Beijing's urban area has been continuously enlarged. The developed area as determined in the 1992 Urban Master Plan, has already been exceeded by additional development areas, en- 


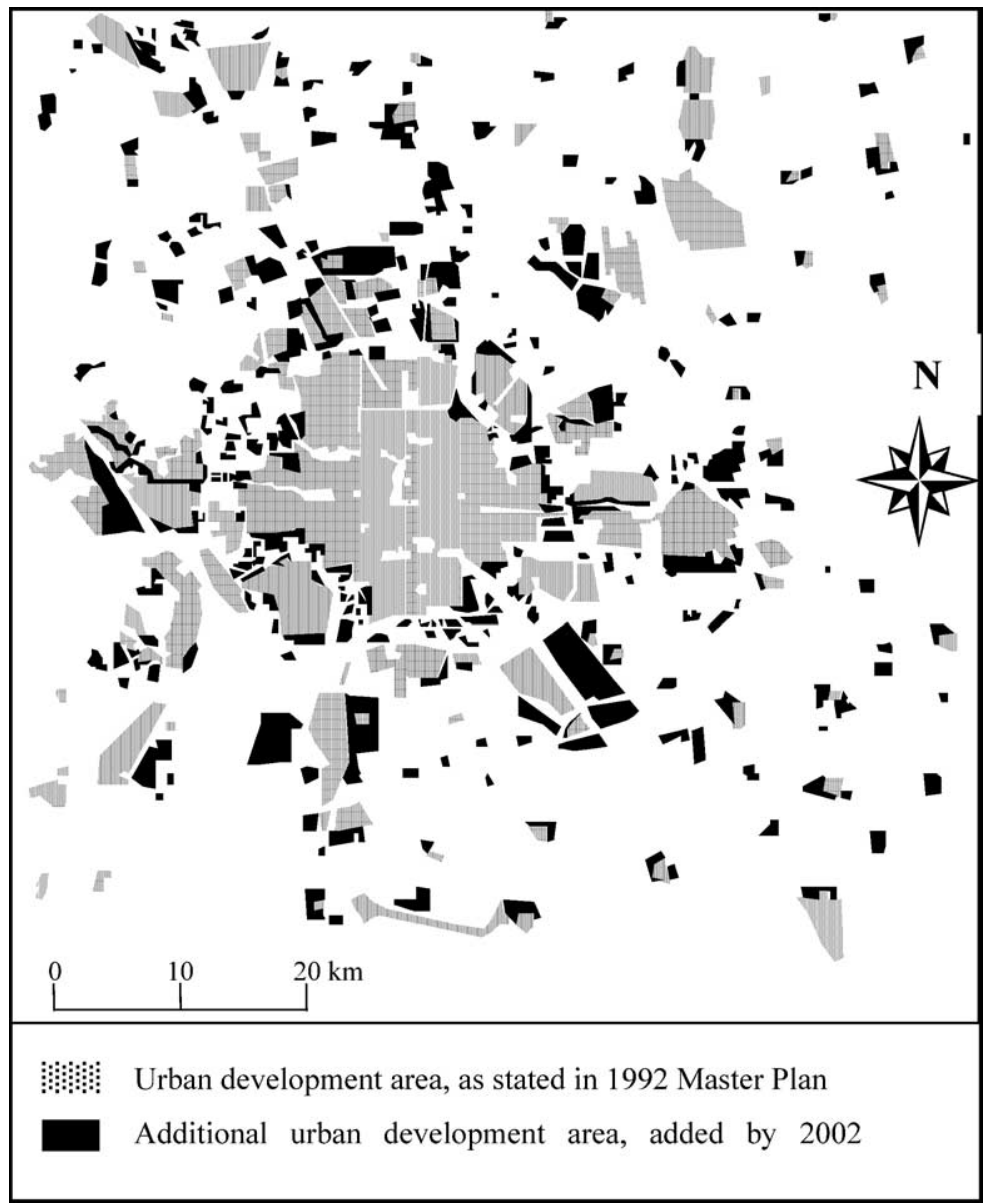

Fig. 2. Extension of urban development area between 1992 and 2002.

croaching vast quantities of agricultural land. These encroachments mainly consist of new settlement development around satellite towns and are mainly located at the transition between the inner city and the suburbs (Fig. 2). From 1992 to 2002, the Beijing settlement area increased by $25 \%$, while the agriculture land decreased by $32 \%$ (Fig. 3). Greenspace also decreased which will have a negative impact on the services provided by these ecosystems for people (Wang et al., 2001).

\subsection{Weaknesses of the current greenbelt}

The current spatial concept of Beijing is based on the 1958 Master Plan and was confirmed in the 1992 Master Plan. It proposed a ring-shaped pattern of high- ways, greenbelts, and satellite towns. The concept consists of two "greenbelts": the inner greenbelt and the outer greenbelt (Fig. 4).

The inner greenbelt is located at the transition between the inner city and the surrounding "satellite towns". The total area of the inner greenbelt still was $314 \mathrm{~km}^{2}$ in the 1958 Master Plan. Due to urban development, it decreased to $240 \mathrm{~km}^{2}$ in the 1992 Master Plan. The development measures in the inner greenbelt were issued by Beijing People's Government on March 29, 2000. One-third of the land was used for residential buildings for farmers, and two-thirds for establishing urban greenspaces in the inner greenbelt. Much has been achieved since 2000, however, due to weak enforcement and particular difficulties with farmers' housing and employment, industrial developments, 


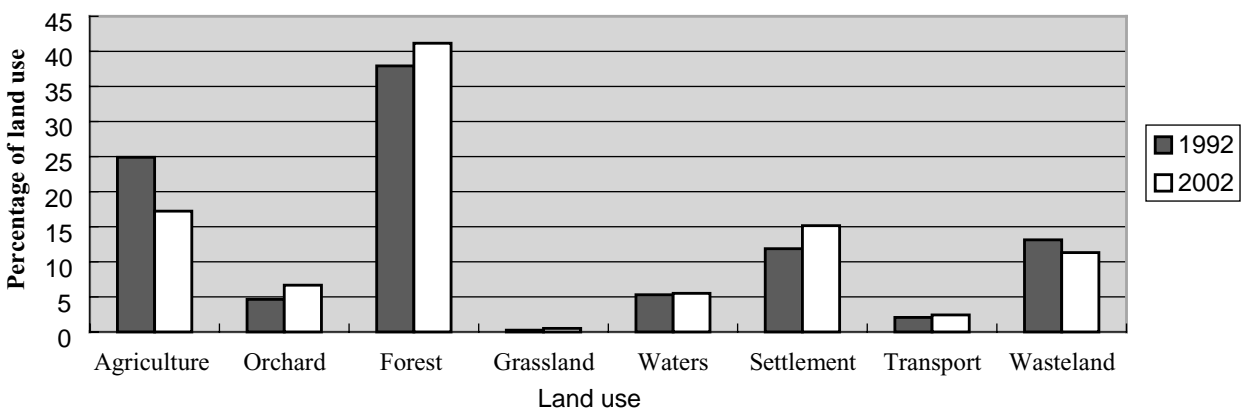

Fig. 3. Land use change in Beijing Province from 1992 to 2002. Wasteland includes urban wasteland and abandoned farmlands.

financing and management, the greenspace is not effectively protected. The most important reason for the encroachment of urban development on greenspace is that there are severe conflicts between real estate development and public interest. Compensation rules for developing greenspace have been established and implemented by Beijing People's Government. Compensation is calculated according to the area of greenspace and its location. Although compensation needs to be paid, this is much less than the economic benefits developers gain from real estate or other business activities. For instance, the financial compensation requested for building over greenspace within the second ringroad is $6000 \mathrm{CNY} / \mathrm{m}^{2}\left(723 \mathrm{US} \$ / \mathrm{m}^{2}\right)$, while the price of new residential floorspace in this area is about 10,000 Yuan.

The planned outer greenbelt is located between the fifth and sixth ringroads, at the transition between the city, suburbs and the rural area. It covers an area of roughly $1650 \mathrm{~km}^{2}$. A planning proposal for the outer greenbelt was produced by the Beijing Environmental Protection Bureau and the Research Center for Eco-Environmental Science, Chinese Academy of Sciences, and was approved by the Beijing People's Government in March 2003. According to the plan, the proposed greenspace coverage is $65 \%$ and the development space should be not more than $20 \%$ in the outer greenbelt. However, the existing urban settlements already accounted for nearly $40 \%$ of the total area of the outer greenbelt. They are mainly residential real estate developments, which try to get extra-benefit from a location surrounded by green areas. While Beijing People's Government has the intention of converting some developed areas into greenspace, the detailed measures are still under research and discussion.

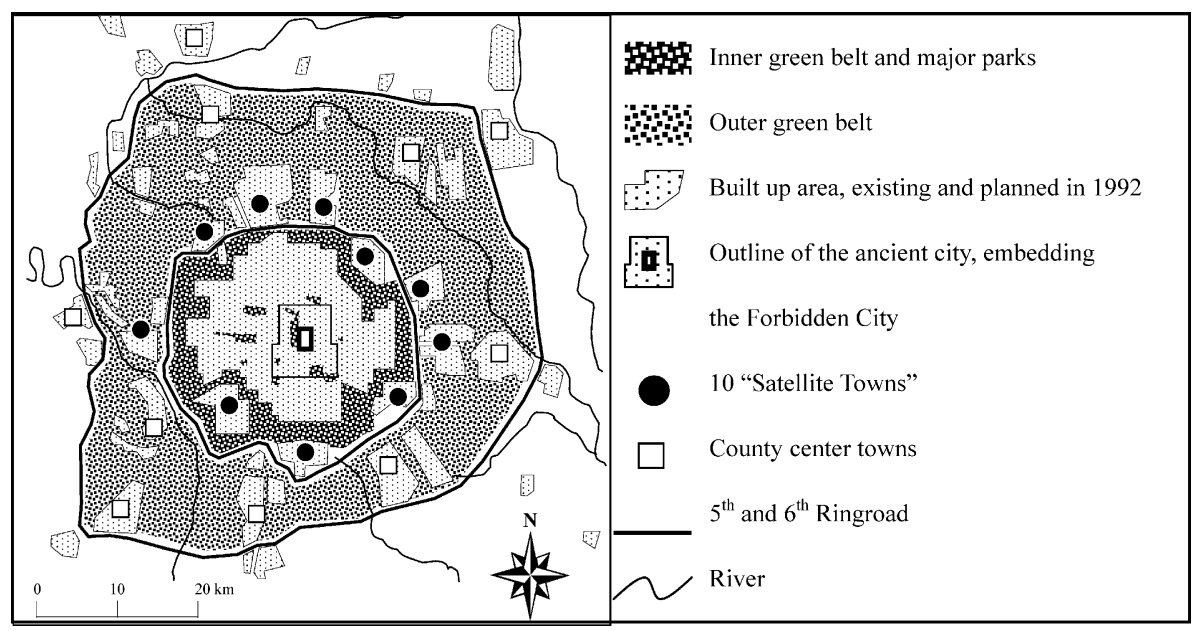

Fig. 4. The two present greenbelts of Beijing in relation to urban development. 
In summary, the two greenbelts have already been fragmented by extensions of settlement areas. The greenbelt areas shown in the planning documents do not conform to reality. Furthermore, the future population increase in Beijing will pose severe pressure on greenspace. Therefore, there is an urgent need for effective protection of greenspace and the development of a rational green and settlement system to counteract uncontrolled development. According to principles of landscape ecology, green wedges and green corridors may be a suitable green network system.

\subsection{Problems of greenspace within the built-up area}

Greenspaces within the built-up area also face problems. The most evident one is that greenspaces are unevenly distributed, and their design emphasizes aspects of beautification rather than ecological and recreational value. Therefore, the spatial pattern of the greenstructure needs to be improved. For instance, a natural forest structure, including a main tree canopy, underlayer shrubs and herbs should be promoted because of plant community stability and the potential for provision of more ecosystem services.

\section{Research approach}

\subsection{Landscape ecological concepts for greenspace planning}

Landscape ecology is the study of interactions among landscape elements. It deals with the effects of the spatial configuration of mosaics on a wide variety of ecological phenomena (Forman and Godron, 1986). Landscape ecology generates understanding of how spatial pattern affects ecological processes. It provides a theoretical basis for landscape and urban planning (Leitão and Ahern, 2002). Forman and Godron (1986) proposed patches, corridors and the matrix as the three basic component types of any landscape. Patches are relatively homogeneous non-linear areas.

Landscape connectivity is the degree of spatial connectedness among landscape elements (Forman, 1995). It has ecological effects on flows of energy, materi- als and biological entities. It is dependent upon both the scale of observation and ecological processes under consideration. A network of patches and corridors can provide connectivity of natural elements and help to preserve linkage between different ecosystems ( Wu and Hobbs, 2002).

\subsection{Ecological principles and requirements for urban greening of Beijing}

According to the analysis of the local situation in Beijing and the problems of urban greening, it was suggested that urban greenspace planning of Beijing should be based on the following landscape ecological principles and requirements (Table 1).

\section{Ecological concept planning of urban greening in Beijing}

\subsection{The temporal and spatial scale of greenspace planning of Beijing}

In greenspace planning of Beijing, three spatial scales are to be considered:

- At the regional scale, the entire area of Beijing Province $\left(16,807.8 \mathrm{~km}^{2}\right)$ is considered. Even the relationship to the neighbor-city Tianjin is included in the plan.

- At the city scale, the urban area of Beijing $\left(1040 \mathrm{~km}^{2}\right)$ with its suburbs, and the surrounding peri-urban zone is taken into account.

- At the neighborhood scale, some selected and typical areas within the fourth ringroad are considered.

The plan distinguishes between three time-scales for implementation:

- Until 2008: The "Green Olympic City". Complete the Olympic Park and other greenings in relation to the Olympic Games 2008.

- Until 2020: The "Modern International City". A modern international Beijing City with distinct characteristics will come into being.

- In the long term: The "Eco-City". A green sustainable ecosystem connected with green wedges, parks and green corridors will be established and improved. 
Table 1

Ecological principles and requirements for the urban greening in Beijing Province

\begin{tabular}{|c|c|}
\hline Principles and requirements & Connotations \\
\hline 1. Structure and function & $\begin{array}{l}\text { 1.1. Changes of greenstructure can cause changes in function } \\
\text { 1.2. Fragmented and isolated greenspace should be integrated into a network }\end{array}$ \\
\hline $\begin{array}{l}\text { 2. Clarity and consistency of } \\
\text { greenspace system }\end{array}$ & $\begin{array}{l}\text { 2.1. An easily-communicable long-term vision } \\
\text { 2.2. An integrated greenspace, division into landscape units with special names and character }\end{array}$ \\
\hline $\begin{array}{l}\text { 3. Functional and ecological } \\
\text { diversity }\end{array}$ & $\begin{array}{l}\text { 3.1. Landscape units and greenspaces combine several ecological functions, and are not } \\
\text { mono-functional } \\
\text { 3.2. Richness of visual experience }\end{array}$ \\
\hline 4. Biodiversity and ecoservices & $\begin{array}{l}\text { 4.1. Enhance ecosystem services by high greenspace quality and diversity } \\
\text { 4.2. Improve specific conditions for endangered species by reducing negative effects on their habitat } \\
\text { (e.g. linkage of fragmented habitats), and by adopting strict regulations for protection }\end{array}$ \\
\hline 5. Accessibility for the public & $\begin{array}{l}\text { 5.1. Bridge separating elements such as road arteries, railroad tracks, river or drainage channels } \\
\text { 5.2. Build a network of footpaths and bicycle routes } \\
\text { 5.3. Interlink the main attractions and recreation areas to high quality public transport, in order to avoid } \\
\text { ecological deterioration of sensitive areas by car transport and parking }\end{array}$ \\
\hline 6. Distribution of greenspace & $\begin{array}{l}\text { 6.1. Public parks close to high-density residential areas } \\
\text { 6.2. No pollution in fresh air-generation zones and fresh air corridors } \\
6.3 \text {. Noise protection }\end{array}$ \\
\hline 7. Integration and transformation & $\begin{array}{l}\text { 7.1. Integration of existing elements: surface water, woods, small parks, and villages } \\
\text { 7.2. Consider growth and change of plants }\end{array}$ \\
\hline 8. Acceptance and implementation & $\begin{array}{l}\text { 8.1. Improve general acceptance of the concept by public participation } \\
\text { 8.2. Publicize the concept through the media } \\
\text { 8.3. Involve decision makers and the public as a strong driving force } \\
\text { 8.4. Promote greenspace development not only as a restriction against over development, but - in a } \\
\text { positive sense - as an essential strategy for quality of life and enrichment of nature ingredients } \\
\text { 8.5. Use the entire range of available legal and fiscal instruments to protect the green system against } \\
\text { over-development. Seek financial contribution from land owners and companies who could gain major } \\
\text { benefits from the green system }\end{array}$ \\
\hline
\end{tabular}

\subsection{Big forest area and ecological buffer belt at the regional scale}

The mountains cover an area of $10,418 \mathrm{~km}^{2}$ and have a length of $700 \mathrm{~km}$ from southwest to northeast of Beijing (Fig. 1). They are the backbone of the regional greenspace strategy for Beijing City. The big forest area in the mountains covers $4057 \mathrm{~km}^{2}$ which accounts for $38.9 \%$ of the mountain area. It should be planned and managed as a large, natural and self-sustaining ecosystem.

At present, the megacities of Beijing and Tianjin form a "dipole" in the Beijing-Tianjin agglomeration. They are already connected by a $100 \mathrm{~km}$ long development axis. In order to organize the greenspaces and enhance their ecological functions, and to prevent excessive urban expansion, two ecological buffer belts with a width of $5-10 \mathrm{~km}$ are proposed (Fig. 5). One buffer belt stretches "from mountain to mountain", and surrounds Beijing (B). It forms the ecological buffer belt in the south of Beijing. Another buffer belt stretches "from sea to sea", providing an ecological buffer belt around Tianjin (T).

These two buffer belts include forest parks, forest belts, nurseries, farmlands, vegetable lands, orchards and shelterbelts against sandstorms. The big forest area and the ecological buffer belt at the regional scale play an important role for enhancing the ecological conditions within and around Beijing by reducing the impacts of sandstorms, store and clean water and maintain biodiversity.

\subsection{Green network system of green wedges, parks and green corridors at the city scale}

Within the city of Beijing, there are six ringroads (Fig. 1). The urban development pattern follows a kind of "pancake" model. This pattern is problematic as 


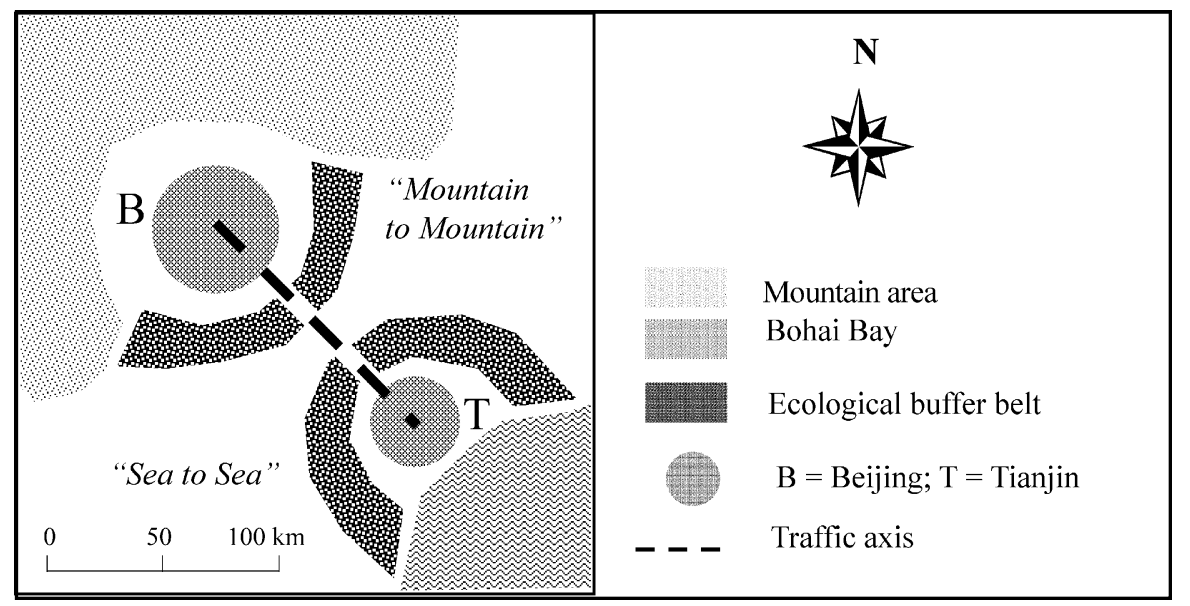

Fig. 5. The ecological buffer belts of Beijing and the nearby Tianjin City.

it can result in traffic jams, excessive sprawl, lack of greenspace, increased "heat island" effect and air pollution (Wang et al., 2001; Jim and Chen, 2003). Unlike the "pancake" urban concept, the "star" settlement structure with green wedges has advantages of mitigating traffic jams, controlling urban extension, offering more greenspace, reducing the "heat island" effect and enhance air ventilation (Bolund and Hunhammar, 1999; Kühn, 2003).

The current greenspaces of Beijing are mainly the public parks, urban forests and agricultural land at the city scale. They are dispersed among the urban area (Fig. 6A). According to landscape ecological principles, and based on an assessment of the existing greenspaces, seven green wedges and some green corridors are proposed from the suburb to the urban center (Fig. 6B). The green wedges are composed of parks, gardens, forest patches, farmlands, rivers and wetlands. These green wedges and green corridors form an integrated ecological network by connecting the urban center, forest parks, mountains and the outer regional space. The settlement and greenstructure proposed at the city scale for the future Beijing is shown in Fig. 7.

In fact, there are already some residential areas within the proposed green wedges and green corridors. A countermeasure would be to remove some of the residential areas. In the case of old single-story suburban and rural houses, it is current practice to remove buildings and resettle the population in other places. In the case of new high-rise building areas, if they cannot be moved, greening within these areas must be improved to increase greenspace cover as a means of enhancing ecosystem services and environmental quality.

The main practical difficulties to the implementation of the greenspace plans at the regional and city scales are as follows:

- Industry and relative service development policy. Industry development often invades the neighboring greenspace.

- Municipal infrastructure construction in existing greenspaces.

- Financing and revenue problems restrict the possibilities to create new greenspaces and manage existing ones.

Beijing People's Government pays increasing attention to these problems. Reviewing the experience from the construction of the inner greenbelt, detailed development controls and measures to forestall intrusion of the planned greenspace are now discussed with a wide range of stakeholders, such as decision-makers, real estate developers, researchers and the public.

\subsection{Green extensions and connections for the gridiron urban form at the neighborhood scale}

The built-up area of Beijing is mostly confined within the fourth ringroad (Fig. 1). Within this built-up area, the general open space pattern has a grid shape. The grid pattern is the traditional mode of urban development in Beijing. It includes blocks, roads, rivers as well as the forest network. Based on the belief that 


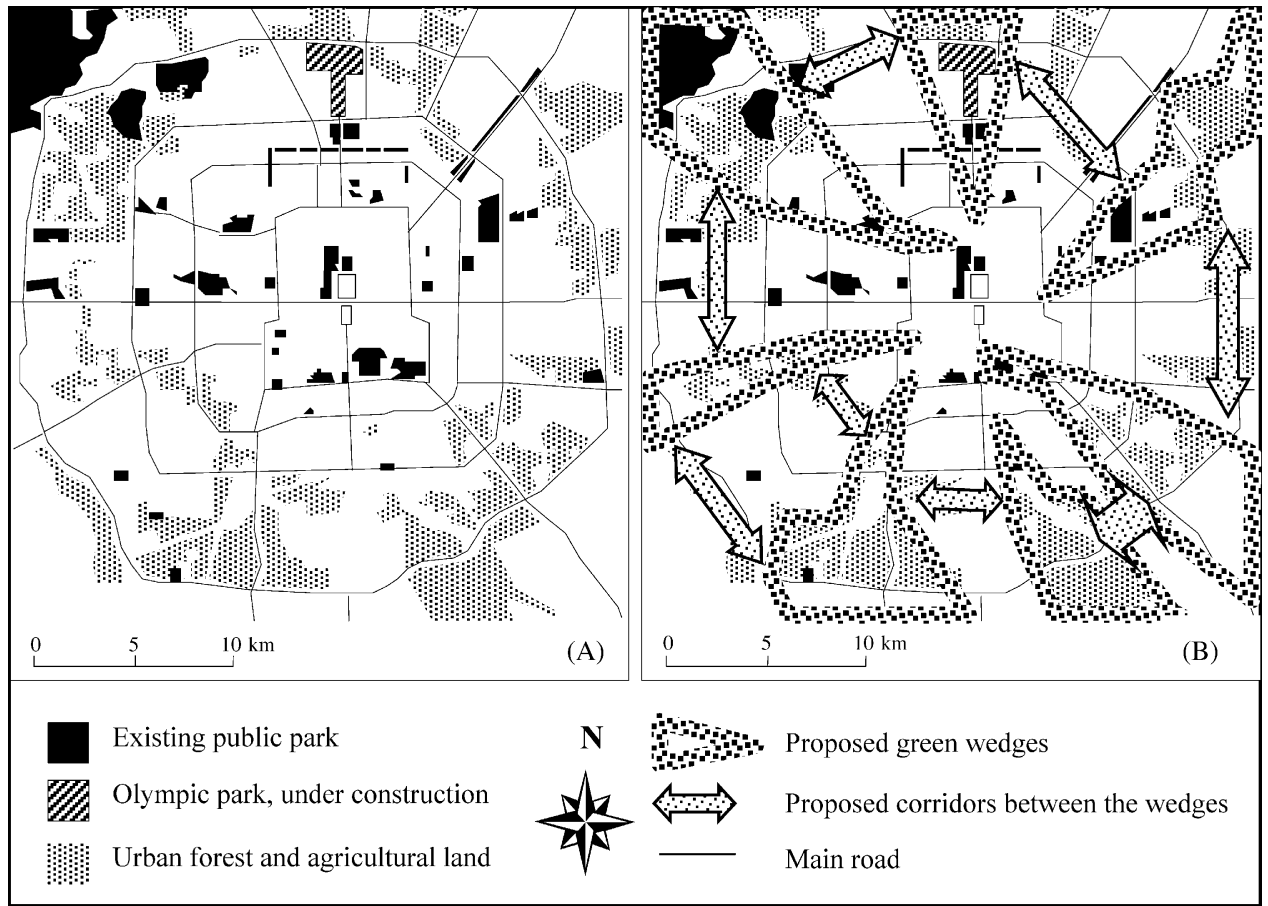

Fig. 6. The existing greenspace vis-a-vis greenspace planning at the city and the neighborhood scale of Beijing: (A) the existing greenspace; (B) proposed green wedges and green corridors based on landscape ecological principles for the future development of Beijing.

the whole is more than the sum of the parts, a system of linkages has been proposed at the neighborhood scale that aims at connecting existing isolated residential greenspaces with public parks and other extensive greenspaces (Jim and Chen, 2003).

\subsubsection{Riverside greenways}

Greenways can be considered linear networks of land, composed of corridors, which are linked to nodes, or patches within the surrounding landscape matrix, thereby providing connectivity throughout the

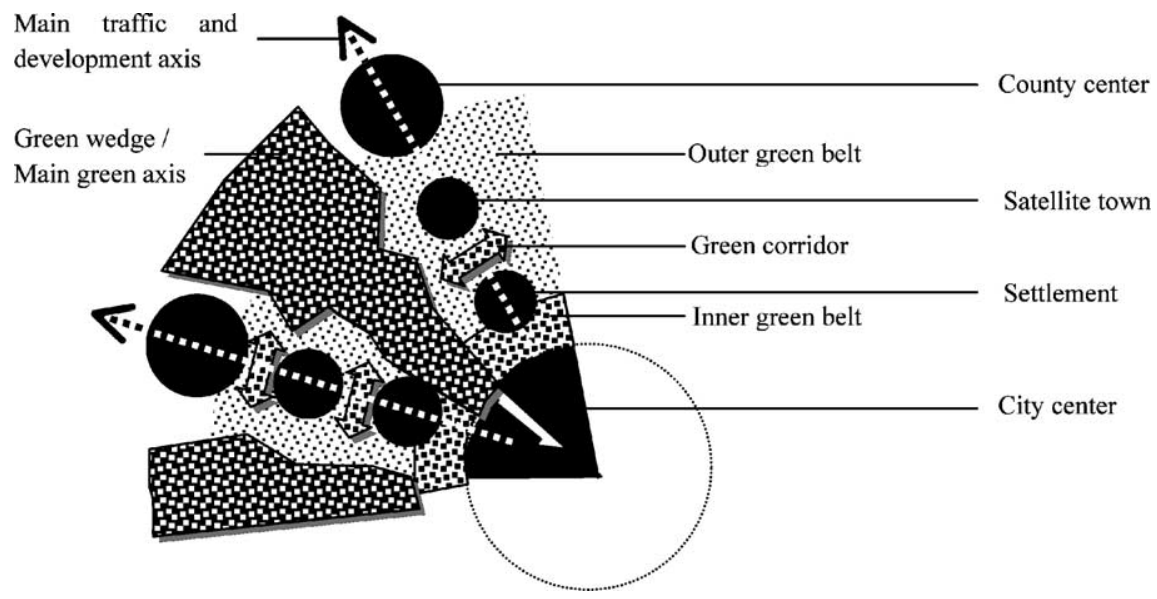

Fig. 7. The settlement and greenstructure proposed at the city scale for the future development of Beijing. 
landscape (Viles and Rosier, 2001). The rivers, canals and lakes within the built-up area of Beijing are the natural greenways for linking the urban greenspace into an integrated unity. The riverside greenway can be used to create recreational open spaces for people with easy access and bring vitality to the downtown areas. Several inner urban rivers of Beijing with the banks built with concrete should be restored by creating natural waterfront. During the last decade, many single-story residential areas, which were located adjacent to rivers and canals, have been removed and substituted by riverside greening. The rivers in the built-up area of Beijing should be connected into a whole network. Riverside greening should encompass a variety of plant species, textures and colors, and be a low-maintenance landscape.

\subsubsection{Road and street greenways}

The ringroads and streets in the built-up area of Beijing create many intersections in the grid system. Roadside trees can separate the traffic lines and the residential zones and reduce noise. The road greenway network can act as an important corridor for people and wildlife. Therefore, they are an important component of the green network in the built-up area. An indigenous-species planting scheme for street trees could promote species diversity. Native tree species should be given priority, supported by systematic identification of suitable candidates by form, texture, growth rate, aesthetic traits, tolerance of urban environmental conditions and maintenance requirements (Jim, 2001). Presently, most roads do not permit such extensive roadside tree planting because of the width, configuration and usage. However, the enlargement and rebuilding of some roads provide opportunities for extensive tree planting. The anticipated difficulties are financing, selection of suitable tree species and space limitations.

\subsubsection{Public parks}

There are 12 main parks in the built-up area of Beijing. The total park area is about 1149 ha (Fig. 6A). Most of them are royal parks. Some parks, such as Beihai and Yuyuantan, include larger water bodies which cover 57 and $44 \%$ of the parks, respectively. Generally, efforts should be made to create a natural forest structure, including a main forest canopy, underlayer trees, shrubs and herbs, to improve ecological condi- tion. Most existing parks do not satisfy such ecological design criteria.

Presently, the distribution of greenspaces in the built-up area is uneven. The preferred distance from home to neighborhood greenspace should be less than $400 \mathrm{~m}$ (Herzele and Wiedemann, 2003). In Beijing, the distance from some residential areas to the next neighborhood greenspace is more than $3 \mathrm{~km}$. In the built-up area, the existing land use does not permit new parks to be set up. Some parks are reconstructed and enlarged when old houses are pulled down. In the suburbs, the chances to create new parks are better. Some new forest parks will be set up within the proposed green wedges. For example, the Olympic Park is now under construction (Fig. 6A). These parks should be configured to connect the green wedges and green corridors to provide proximity to residents.

\subsubsection{Vertical greening for high-density settlement}

In the built-up area of Beijing, in particular in the old city core, the acute conflicts between highdensity development and limited land have led to crowded communities with inadequate open space for humans and wildlife. Vertical greening could help to ease this problem. It includes roof gardens, wall greening, balcony greening, and windowsill greening. Vertical greening can augment the leaf area index of greenspace to enhance the ecological functions. It is an effective way for increasing greenspace of high-rise building areas adopted by some Chinese cities, such as Chengdu, Shanghai, Nanjing and Beijing City (Xu et al., 1999). There is great potential to develop vertical greening in Beijing. But there are also difficulties in implementation, such as plants selection, soil thickness and water supply.

\section{Discussion}

This paper develops an integrated green network system at three levels for Beijing Province based on principles of landscape ecology. Compared with others' work, the proposal for the greenspace planning of Beijing is more conceptual and multidimensional. It is planned at the regional, city and neighborhood levels. It takes into account landscape ecological principles but also the needs of people of greenspace for recreation. Flores et al. (1998) proposed ecological 
principles for the development of a greenspace system for the New York City region. They particularly focused on the relationship of landscape structure and function. This is also an important approach considered in this paper. Jim and Chen (2003) applied landscape ecological principles to the greenspace planning of Nanjing City, China. They mainly focused on the whole metropolis area of Nanjing and are more detailed in planning and design.

In future, new ecological indicators should be developed for urban planning for sustainable development (Diamantini and Zanon, 2000). The traditional indicator of greenspace coverage (the percentage of green land area on a site) does not reflect the quality of greenstructure, nor does it represent the variety of ecosystem services of greenspace. The ecological indicator of green plot ratio provides an effective method to assess the quality of greening in urban planning (Ong, 2003). It will be applied in the next step of greenspace design in Beijing.

A city is a complex ecosystem composed of natural, social, economic and scientific subsystems (Ma and Wang, 1984). In addition to natural factors, social, economic and scientific aspects play an important role in the planning and management of urban greenspaces, and more widely the urban environment (Shafer, 1999; Landelma et al., 2000; Pauleit and Duhme, 2000). Improving the participation of all stakeholders, and better coordination of planning institutions are crucial for success (Landelma et al., 2000; Tahvanainena et al., 2001).

After completion of this study, we discussed the results with politicians and planners from the Beijing Municipal Institute of City Planning and Design and Beijing People's Government. There was agreement that this strategy would help to meet the challenges of future urban development in Beijing and it is intended to implement it step by step. Until now, the public views have not been gauged in a survey, but there are several sources reflecting public views. These include newspapers, internet discussions, conferences and meetings attended by decision-makers, real estate developers, researchers and the public. In future, the planning should be presented to the public by Beijing People's Government, and more consideration should be given to public opinions from all layers of the society in the next step of implementation.

However, there are still some limitations in our study. Our greenspace planning is conceptual and not elaborated in detail. Some works such as the selection of plant species and establishment of management measures still need to be studied and designed. The landscape ecological principles and requirements outlined in this paper need not only qualitative explanation, but also quantitative evaluation in future research.

In order to realize this plan, the measures regarding legal, economic, institutional, social and technological aspects need further research. Measures to protect greenspace effectively require particular attention. Compensation schemes, that reflect the real value of greenspaces, could become one of the most important measures to accomplish this task. Some greenspaces at strategic locations should be strictly protected. Urban parks, forestry, agriculture, waters and infrastructure should be planned and designed as an integrated system. Furthermore, the planning and management of urban greenspaces and the wider landscape of Beijing must proceed hand in hand with surrounding regional land use planning of Tianjin metropolis and Hebei Province.

No papers about Beijing's greenspace planning have been published in international journals. This study contributes to fill this gap.

\section{Acknowledgements}

This research is financially supported by the Knowledge Innovation Project of Chinese Academy of Sciences (No. KZCX3-SW-424). We are grateful to the Beijing Municipal Institute of City Planning and Design for providing information on urban planning and development. Finally, we thank Dr. Stephan Pauleit for his constructive suggestions for twice revising and polishing the manuscript.

\section{References}

Attwell, K., 2000. Urban land resource and urban planting-case studies from Denmark. Landscape Urban Plann. 52, 145-163.

Beijing Municipal Statistical Bureau, 2002. Beijing Statistical Yearbook. China Statistics Press, Beijing (in Chinese).

Bolitzer, B., Netusil, N.R., 2000. The impact of open spaces on property values in Portland. Oregon J. Environ. Manage. 59, 185-193.

Bolund, P., Hunhammar, S., 1999. Ecosystem services in urban areas. Ecol. Econ. 29, 293-301. 
Bradley, G.A., 1995. Urban Forestry Landscapes: Integrating Multidisciplinary Perspectives. University of Washington Press, Seattle.

Costanza, R., d'Arge, R., de Groot, R., Farber, S., Grasso, M., Hannon, B., Laskin, R., Sutton, P., van den Belt, M., 1997. The value of the world's ecosystem services and natural capital. Nature 387 (15), 253-260.

de Groot, W.T., van den Born, R.J.G., 2003. Visions of nature and landscape type preferences: an exploration in The Netherlands. Landscape Urban Plann. 63, 127-138.

Diamantini, C., Zanon, B., 2000. Planning the urban sustainable development the case of the plan for the province of Trento, Italy. Environ. Impact Assess. Rev. 20, 299-310.

Flores, A., Pickett, S.T.A., Zipperer, W.C., Pouyat, R.V., Pirani, R., 1998. Adopting a modern ecological view of the metropolitan landscape: the case of a greenspace system for the New York City region. Landscape Urban Plann. 39, 295-308.

Forman, R.T.T., 1995. Land Mosaics: The Ecology of Landscapes and Regions, second ed. Cambridge University Press.

Forman, R.T.T., Godron, M., 1986. Landscape Ecology. Wiley, New York.

Grey, G.W., 1996. The Urban Forest: Comprehensive Management. Wiley, New York.

Herzele, A.V., Wiedemann, T., 2003. A monitoring tool for the provision of accessible and attractive urban green spaces. Landscape Urban Plann. 63, 109-126.

Jim, C.Y., 2001. Managing urban trees and their soil envelopes in a contiguously developed city environment. Environ. Manage. 28 (6), 819-832.

Jim, C.Y., Chen, S.S., 2003. Comprehensive greenspace planning based on landscape ecology principles in compact Nanjing City, China. Landscape Urban Plann. 65, 95-116.

Jo, H.K., 2002. Impacts of urban greenspace on offsetting carbon emissions for middle Korea. J. Environ. Manage. 64, 115-126.

Kühn, M., 2003. Greenbelt and green heart: separating and integrating landscapes in European city regions. Landscape Urban Plann. 64, 19-27.

Landelma, R., Salminen, P., Hokkanen, J., 2000. Using multicriteria methods in environmental planning and management. Environ. Manage. 26 (6), 595-605.

Leitão, A.B., Ahern, J., 2002. Applying landscape ecological concepts and metrics in sustainable landscape planning. Landscape Urban Plann. 59, 65-93.

Li, F., Wang, R.S., 2003. Evaluation, planning and prediction of ecosystem services of urban green space: a case study of Yangzhou City. Acta Ecol. Sin. 23 (9), 1929-1936 (in Chinese).

Luttik, J., 2000. The value of trees, water and open space as reflected by house prices in The Netherlands. Landscape Urban Plann. 48, 161-167.

Lütz, M., Bastian, O., 2002. Implementation of landscape planning and nature conservation in the agricultural landscape-a case study from Saxony. Agric. Ecosyst. Environ. 92, 159-170.
Lynn, N.A., Brown, R.D., 2003. Effects of recreational use impacts on hiking experiences in natural areas. Landscape Urban Plann. 64, 77-87.

Ma, S.J., Wang, R.S., 1984. Social-economic-natural complex ecosystem. Acta Ecol. Sin. 4 (1), 1-9 (in Chinese).

Miller, R.W., 1988. Urban Forestry: Planning and Managing Urban Green Spaces. Prentice-Hall, Englewood Cliffs, NJ.

Ong, B.L., 2003. Green plot ratio: an ecological measure for architecture and urban planning. Landscape Urban Plann. 63, 197-211.

Pauleit, S., Duhme, F., 2000. Assessing the environmental performance of land cover types for urban planning. Landscape Urban Plann. 52, 1-20.

Pauleit, S., Slinn, P., Handley, J., Lindley, S., 2003. Promoting the natural greenstructure of towns and cities: English Nature's Accessible Natural Greenspace Standards Model. Bull. Environ. 29 (2), 157-171

Savard, J.-.P.L., Clergeau, P., Mennechez, G., 2000. Biodiversity concepts and urban ecosystem. Landscape Urban Plann. 48, 131-142.

Schell, L.M., Ulijaszek, S.J., 1999. Urbanism, Health and Human Biology in Industrialized Countries. Cambridge University Press, Cambridge.

Shafer, C., 1999. US National park buffer zones: historical, scientific, social, and legal aspects. Environ. Manage. 23 (1), 49-73.

Sousa, C.A.D., 2003. Turning brownfields into green space in the city of Toronto. Landscape Urban Plann. 62, 181-198.

Tahvanainena, L., Tyrvainena, L., Ihalainena, M., Vuorelab, N., Kolehmainenc, O., 2001. Forest management and public perceptions-visual versus verbal information. Landscape Urban Plann. 53, 53-70.

Tarrant, M.C., Cordell, H.K., 2002. Amenity values of public and private forests: examining the value-attitude relationship. Environ. Manage. 30 (5), 692-703.

Teal, M., Huang, C.S., Rodiek, J., 1998. Open space planning for Travis Country, Austin, Texas: a collaborative design. Landscape Urban Plann. 42, 259-268.

Thompson, C.W., 2002. Urban open space in the 21 st century. Landscape Urban Plann. 60, 59-72.

Tyrväinen, L., 2001. Economic valuation of urban forest benefits in Finland. J. Environ. Manage. 62, 75-92.

Viles, R.L., Rosier, D.J., 2001. How to use roads in the creation of greenways: case studies in three New Zealand landscapes. Landscape Urban Plann. 55, 15-27.

Wang, R.S., Chi, J., Ouyang, Z.Y., 2001. Eco-Integration for Sustainable Development of Middle and Small Sized Towns. Meteorologic Press, Beijing (in Chinese).

Wu, J.G., Hobbs, R., 2002. Key issues and research priorities in landscape ecology: an idiosyncratic synthesis. Landscape Ecol. 17, 355-365.

Xu, X.C., Zuo, L.P., Wang, B.C., 1999. Develop vertical greening and enhance urban greenspace. Chin. Landscape Arch. 15 (62), 49-50 (in Chinese). 